\title{
COMPARING FACTORS CONDITIONING LANDSCAPE CHANGE DURING VOLCANIC ERUPTION AT VIRUNGA NATIONAL PARK, EAST AFRICA
}

\author{
UDAHOGORA, M. ${ }^{1,2}-$ YANG, Z. P..$^{1,2 *}$-NZABARINDA, V. ${ }^{1,2}-$ AKBAR, I. ${ }^{1,2}-$ MiNDJE, R. ${ }^{1,2}$ \\ UMWALI, E. D. ${ }^{1,2}$ \\ ${ }^{1}$ State Key Laboratory of Desert and Oasis Ecology, Xinjiang Institute of Ecology and \\ Geography, Chinese Academy of Sciences, Urumqi 830011, China \\ ${ }^{2}$ University of Chinese Academy of Sciences, Beijing 100049, China \\ *Corresponding author \\ e-mail:yangzp@ms.xjb.ac.cn \\ (Received $10^{\text {th }}$ Apr 2021; accepted $12^{\text {th }}$ Aug 2021)
}

\begin{abstract}
The change on Virunga National Park (VNP) landscape due to climate change, anthropogenic activities and natural disasters calls for appropriate monitoring and management policies. This study aimed to assess and compare the factors conditioning landscape change during volcanic eruption at VNP located in the East Africa from 1990 to 2018. Land use and land cover Landsat 5 images of 1990 and 2004, and Landsat 8 images of 2018 were analyzed by the supervised maximum likelihood classification techniques. The calculation of Normalized Difference Vegetation Index (NDVI) and its relationship with precipitation and temperature referred to the same images. Remote Sensing (RS) and Geographic Information System (GIS) facilitated data analysis. The results highlighted human activities as key drivers to landscape changes recorded in the central and northern parts. The southern part recorded high extent of changes which transformed $8.36 \mathrm{Km}^{2}$ of the park into new lava flow linked to $11.6 \mathrm{Km}^{2}$ of grassland and almost $1 \mathrm{Km}^{2}$ of shrubland changed into lava plains. The two volcanoes are associated with volcanic plume and gas emission, which mainly cause NDVI perturbation. This study can serve as a baseline in the conservation and management of protected areas and reduction of volcanic effects on national parks.
\end{abstract}

Keywords: landscape change, NDVI, rainfall and temperature, Virunga National Park, volcanic eruption

\section{Introduction}

In 1972, the World Heritage Convention was approved to facilitate the conservation in the continuity of the most valuable cultural and natural resources of the world (Meskell, 2013). The convention's goal is to protect resources that possess significant universal values that rise above national boundaries and deserve safeguarding for the benefit of humanity. There are more than 190 countries that are co-signers to the convention, devoting to protect the 1,121 world heritage sites. Out of these properties, 213 are Natural World Heritage Sites (NWHS), adorned for their exceptional natural glamour, biological essence and biodiversity conservation (Edwards Jr. et al., 2018; Lin et al., 2020). NWHSs serve as crucial sources of water, prevention of natural disasters such as landslides or floods, job creation and income generation from tourism and recreation, and provision of habitat to wildlife while the varying human and natural events threaten this natural asset (Osipova et al., 2014).

For example, two most active volcanoes in Africa are Nyiragongo and Nyamuragira located to the south of VNP registered recent eruption. Between 1977 and 2002, Nyiragongo had flank eruptions that led to injuries and deaths, which ultimately triggered socio-economic and humanitarian disasters (Tazieff, 1977; Vaselli et al., 2010; Cuoco et al., 2013). Nyamulagira's lava flow field located in the VNP covers more than $1,100 \mathrm{~km}^{2}$. 
Nyamulagira's flank eruptions are associated with the burning of vast hectares of the protected forest and its lava flow destroyed 10-13\% of Goma, which rendered about 120,000 persons homeless, and affected the regional economy (Allard et al., 2002; Baxter and Ancia, 2002; Tedesco et al., 2002). Additionally, both Nyamuragira and Nyiragongo emit acidic gas flumes that are highly concentrated with Sulphur dioxide $\left(\mathrm{SO}_{2}\right)$ (including ash) which contributes to the acidic rainfall affecting the surface water quality, crops, vegetation, human infrastructure, and human health (Vaselli et al., 2010; Cuoco et al., 2013; Balagizi et al., 2018).

According to Mitchell et al. (2015) and Rolo et al. (2018), the volcanic eruption causes fragmentation of a landscape which generates both negative and positive effects. For instance, Ibáñez et al. (2014) researched the impact of landscape fragmentation on vegetation and reported significant positive effects resulted from the edge effects and fragment size. Negative responses to edge effects were vital for survival, density, colonization, and richness. The study of Mitchell et al. (2015) evaluated the correlation between ecosystem services and landscape integration. The researchers claim that disintegration can have both negative and positive impacts on service flow, although it generally affects the ecosystem service supply negatively. The effects of disintegration are a result of landscape fragmentation being able to facilitate and intersect the movement of substance, energy, organisms, and persons across landscapes (Mitchell et al., 2015). Notably, landscape fragmentation contributes to diminishing the mean forest patch size and increasing the density of the forest patch, which consequently affects the species habitat (Andren, 1994; Estoque et al., 2018).

Volcanic eruptions change the landscape through constructive (pyroclastic deposits, lava flows, and domes) and descriptive (caldera creation and flank failure) processes. More specifically, volcanic eruptions are destructive to plant life and also alter the physical properties land, for instance, porosity, chemistry, and permeability (Mutaqin et al., 2019; Michellier et al., 2020). Previous studies (Marijnen, 2018; Christensen and Arsanjani, 2020) on VNP focus on the effects of volcanic particles on vegetation but omitted the impact of volcanic eruptions on the change on VNP's landscape. The literature indicates lack of implications of lava flow, volcanic emissions, and volcanic plume deposits on the wildlife and their habitat, mainly chimpanzees living on the side of Nyamuragira's lava plains in the Tongo forest.

Remote sensing technology remains to be a key data source for various environmental sciences and activities monitoring, for instance, assessment of change in forest cover (Desclee et al., 2013; Binsangou et al., 2018; Pareta and Pareta, 2019). In addition, land use/land cover (LULC) maps resulting from remote sensing imageries provide valuable information for capturing landscape structure and spatial formation (Estoque et al., 2018; Orimoloye et al., 2019). The authors applied Remote Sensing techniques to assess the impact of volcanic eruption to landscape change at Virunga National Park, East Africa. Satellite images were taken on $18^{\text {th }}$ October, 1990; $26^{\text {th }}$ October 2004 and finally $6^{\text {th }}$ November, 2018.

\section{Methods and Materials}

\section{Description of study area}

This study considered the Virunga National Park (VNP) located in the East Africa at $0^{0} 55^{\prime} \mathrm{S}, 29^{0} 10^{\prime} \mathrm{E}$, in the Albertine Rift Valley situated in the eastern Democratic Republic of Congo. It ranges from 2,230 ft in the Semliki River valley to 16,762 ft in altitude. From 
south to north, it encompasses about $300 \mathrm{Km}$ and covers an area of 7,900 $\mathrm{km}^{2}$. The area is mainly along the international boundaries with Rwanda and Uganda in the eastern part (Crawford and Bernstein, 2008). The VNP (Figure 1) shares border with the Democratic Republic of Congo, Uganda and Rwanda.

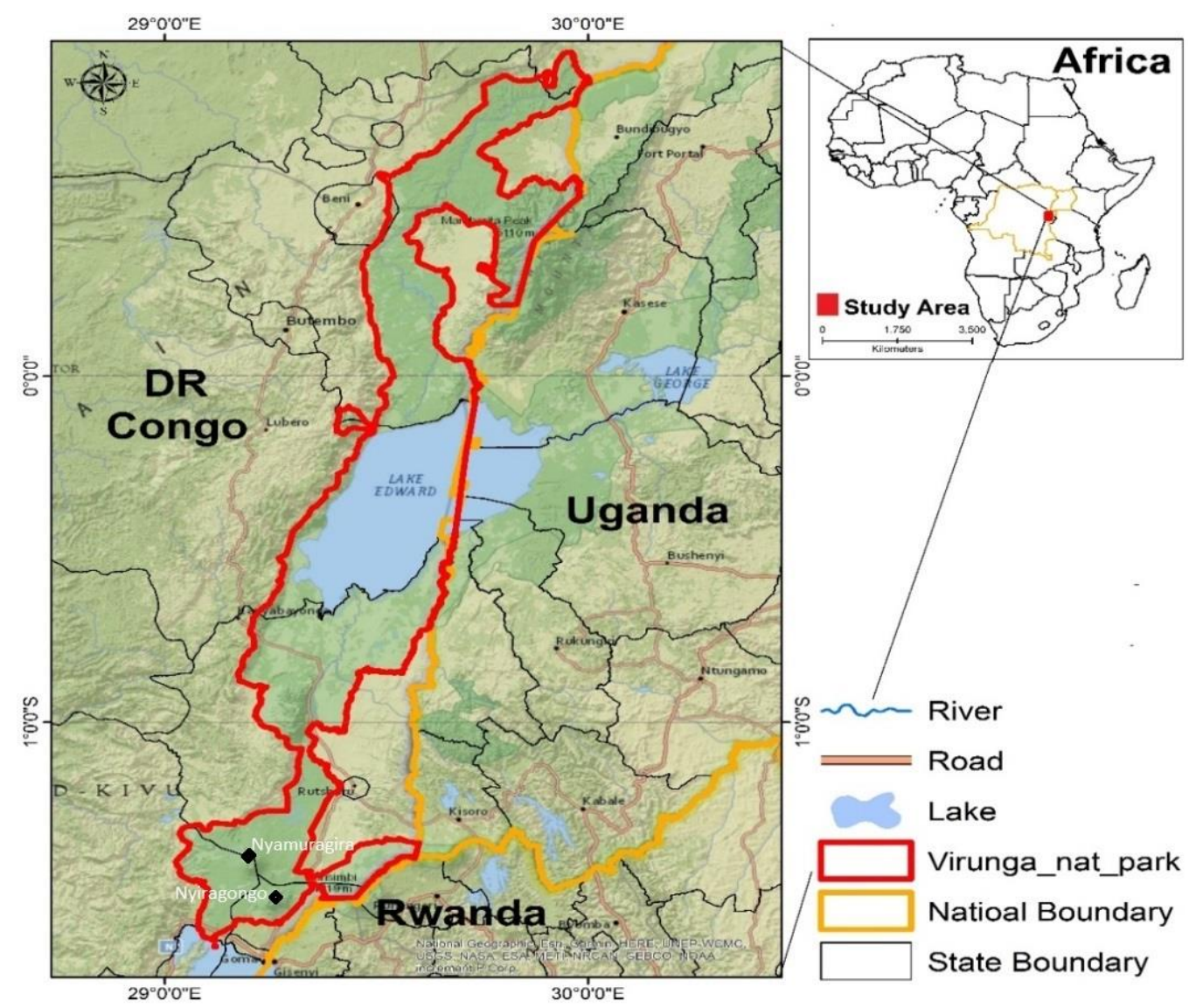

Figure 1. Map indicating the location of the study area

\section{Datasets collection and Analysis}

For this study, the authors utilized remote sensing satellite images in order to assess the LULC of the area in the years of 1990, 2004, and 2018. These Landsat images were acquired from: https://glovis.usgs. gov/. The 1990-2004 and 2004-2018 images were related to the spatio-temporal landscape changes in VNP and chimpanzee population in the Tongo forest, part of VNP. This period covered both before and after volcanoes major events during the 28 years (Nyiragongo in 2002 and Nyamuragira in 2010-2011).

The analysis of LULC changes of VNP was made by using both Landsat5 images of 1990 and 2004 along with Landsat 8 images of 2018. The LULC classified images were separately classified into seven classes namely: bare area, cropland, forest, grassland, shrubland, water, and wetland. The LULC images were classified with reference to the supervised maximum likelihood classification techniques (Orimoloye et al., 2019). The method necessitates the digitization of training places for every LULC session based on the prior knowledge, and uses the training locations to train and ultimately categorize pixels into the images (Estoque et al., 2018). Atmospheric correction was done using below equation. 


$$
p_{\lambda}=\frac{\left[\left(L_{\lambda}-L_{p 1 \%}\right) * \mathrm{pi} * d^{2}\right]}{\left[T_{v^{*}}\left(E S U N * \cos (z) * T_{z}+E_{\text {down }}\right) \quad\right]}
$$

were $p_{\lambda}$ is the planetary reflectance (Unitless), $L_{\lambda}$ is the cell value as spectral at sensor radiance, $\mathrm{d}$ is the earth-sun distance (astronomical unit), ESUM is the mean solar exoatmospheric irradiances, $\mathrm{T}$ is the atmospheric transmittance (Unitless), $\mathrm{E}$ is the emissivity and $\mathrm{z}$ is the local sun elevation angle.

Moreover, the study evaluated the Normalized Difference Vegetation Index (NDVI) by utilizing the same Landsat images. However, different bands were used in order to explain difference of the spectral responses of vegetation at the near-infrared and red bands (Mind'je et al., 2019). The values of NDVI were calculated by using the equation below.

$$
N D V I=\frac{\rho_{\text {nir }}-\rho_{\text {red }}}{\rho_{\text {nir }}+\rho_{\text {red }}}
$$

The NDVI varies between -1.0 and +1.0 .

However, the authors recognized the fact that NDVI can be affected by vegetation health, seasonality effects, atmospheric effects, and topography, for instance, sun angle (DeRose et al., 2011). Therefore, climatic variables of precipitation and average temperature were used to determine NDVI-precipitation and temperature relationships (Ndayisaba et al., 2017) by using the equation below. The dark object subtraction technique was applied to achieve surface reflectance and full atmospheric correction as described using Equation 2 (Song et al., 2001).

$$
S=\frac{n \sum_{i=1}^{n} X_{i} Y_{i}-\sum_{i=1}^{n} X_{i} \sum_{i=1}^{n} Y_{i}}{n \sum_{i=1}^{n} X_{i}^{2}-\left(\sum_{i=1}^{n} X_{i}\right)^{2}}
$$

where $\mathrm{S}$ is the slope, $\mathrm{Y}_{\mathrm{i}}$ and $\mathrm{X}_{\mathrm{i}}$ are the dependent variable values and the independent variable in the $i^{\text {th }}$ year, respectively, and $\mathrm{n}$ is the total number of years considered by the study. Generally, if slope $=0$, the dependent variable shows stability. On the other hand, if the slope $>0$, the variation dependent variable values indicate an increasing trend, whereas when the slope is $<0$, the dependent variable variation implies a decreasing trend.

The above data sets were collected and analyzed by using both Remote Sensing (RS) and Geographic Information System (GIS) and their corresponding maps are presented in the following section.

\section{Classification accuracy assessment}

Furthermore, the authors considered the fact that accuracy exposes the exactness between a truthful standard expected and the image classified of unidentified quality, and that when only using general classes, the user of the map cannot make observations about a selected point on the map with precision (Rwanga and Ndambuki, 2017). Also, it is practical to increase the accuracy of any classification in the GIS environment by integrating numerous classes instead of a specific feature or by decreasing the number of details. More specifically, lower precision is associated with higher accuracy (MacLean and Congalton, 2012). Therefore, in order to ensure the accuracy of the processed image, the authors performed an accuracy assessment.

Furthermore, in order to indicate the impact of volcanic eruption on the landscape change and its wildlife habitat mainly chimpanzee in Tongo forest, the largely affected 
by change on landscape. This exercise was completed by referring to secondary sources which considered the change on the number of chimpanzee, area fragmentation due to landscape change resulting volcanic eruption. All sources used for this track of chimpanzee change were provided in the reference list.

\section{Result and Discussions}

\section{Spatial patterns of land use and land cover between 1990 and 2018}

The results of the study in Figure $2 A$ and Table 1 indicated that in 1990, the forest occupied the most substantial areas in all the seven land feature types, with about $40 \%$ $\left(3119 \mathrm{Km}^{2}\right)$ of the entire land cover in the area. The smallest percentage was occupied by wetland at $0.18 \%\left(13.9 \mathrm{Km}^{2}\right)$ of the total area (Figure $\left.2 A\right)$. In 2004, about $0.75 \%$ of forests declined compared to 1990 . However, cropland increased by $1.18 \%$, while water and grassland declined by $0.5 \%$ and $0.027 \%$, respectively (Figure $2 B$ and Table 1). Finally, the bare area increased by $0.21 \%$, while shrubland and wetland decreased by $0.034 \%$.

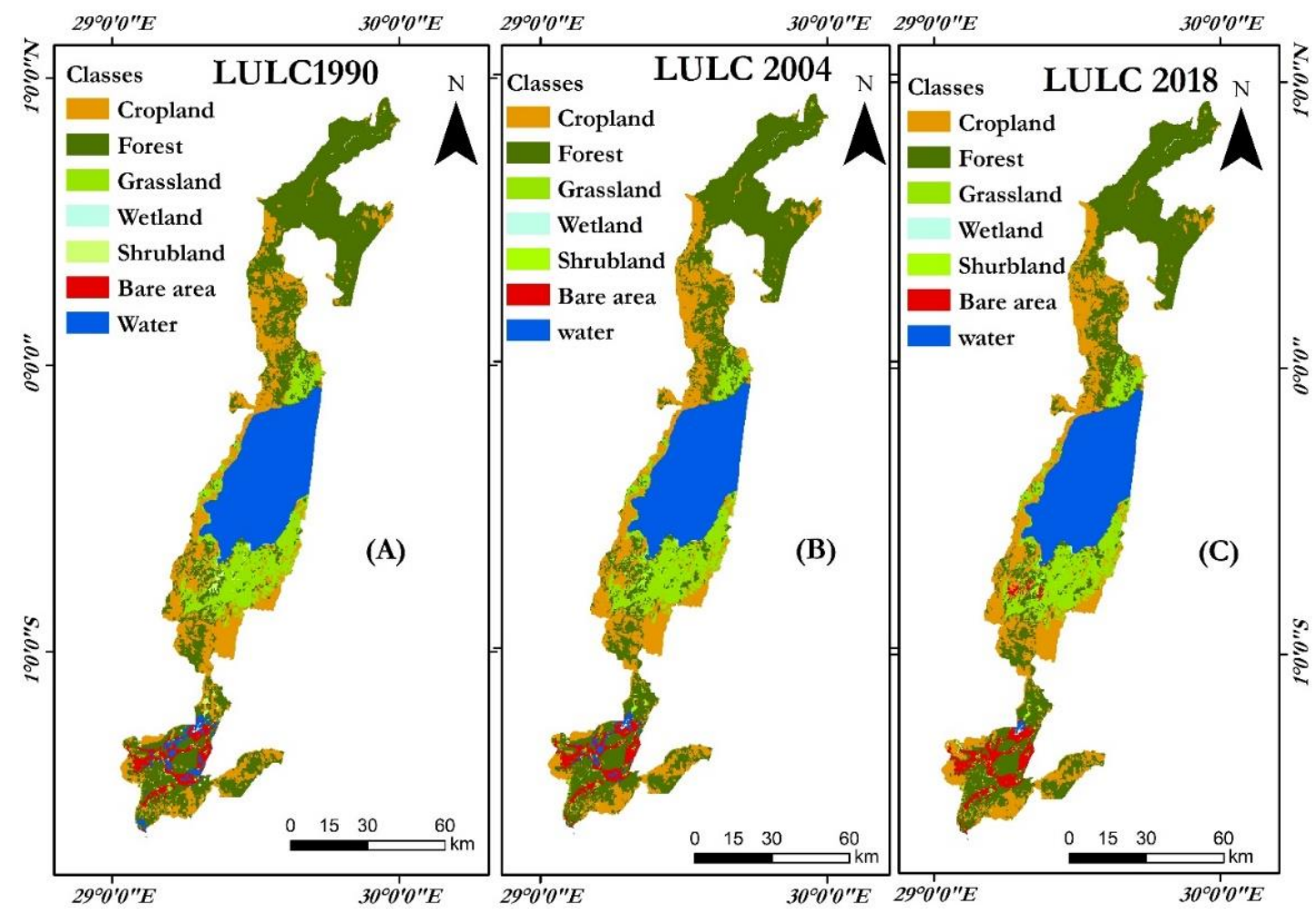

Figure 2. Land use and land cover at Virunga National Park 1990 (A), 2004 (B), 2018 (C)

Generally, there is a higher landscape change between 1990 and 2004. From 2004 to 2018 , the area occupied by water and forest declined by about $0.56 \%$, while grassland decreased by $0.12 \%$. Cropland increased by $0.41 \%$, and the bare area increased by $0.77 \%$, shrubland increased by $0.042 \%$ while the wetland area rose by $0.015 \%$ (Figure 3). Between 1990 and 2018, there was an increase of cropland, shrubland, and bare area by $1.59 \%, 0.008 \%$ and $0.97 \%$, respectively (Figure 3). While forest declined by $1.29 \%$, grassland, wetland, and water decreased by $0.15 \%, 0.018 \%$, and $1 \%$, respectively. 
Table 1. LULC change matrix from 1990 to $2018\left(\mathrm{Km}^{2}\right)$

\begin{tabular}{|c|c|c|c|c|c|c|c|c|c|}
\hline \multirow{10}{*}{ LULC 1990} & \multicolumn{9}{|c|}{ LULC 2004} \\
\hline & Classes & Cropland & Forest & \multicolumn{4}{|c|}{ Grassland Wetland Shrubland Bare Area } & \multirow{2}{*}{$\begin{array}{c}\text { Water } \\
0\end{array}$} & \multirow{2}{*}{\begin{tabular}{|c} 
Grand Total \\
1757.37
\end{tabular}} \\
\hline & Cropland & 1667.54 & 89.73 & 0 & 0 & 0 & 0.1 & & \\
\hline & Forest & 180.33 & 2936.24 & 2.57 & 0.09 & 0.29 & 0.38 & 0.0000021 & 3119.9 \\
\hline & Grassland & 1.33 & 3.61 & 879.16 & 0 & 0 & 0 & 0 & 884.11 \\
\hline & Wetland & 0 & 2.76 & 0 & 11.22 & 0 & 0 & 0 & 13.97 \\
\hline & Shrubland & 0 & 4.18 & 0 & 0 & 53.13 & 0 & 0.1 & 57.41 \\
\hline & Bare Area & 0 & $2.23 \mathrm{E}-06$ & 0 & 0 & 0 & 217.21 & 0.0000012 & 217.21 \\
\hline & Water & 0.29 & 26.04 & 0.28 & 0 & 1.33 & 16.06 & 1725.02 & 1769.02 \\
\hline & Grand Total & 1849.49 & 3062.56 & 882.01 & 11.31 & 54.75 & 233.74 & 1725.12 & 7818.99 \\
\hline \multirow{10}{*}{ LULC 2004} & \multicolumn{9}{|c|}{ LULC 2018} \\
\hline & Classes & Cropland & Forest & Grassland & Wetland & Shrubland & Bare Area & Water & Grand Total \\
\hline & Cropland & 1825.15 & 14.74 & 0 & 0 & 0 & 9.6 & 0 & 1849.49 \\
\hline & Forest & 57.11 & 2992.34 & 1.9 & 1.24 & 1.52 & 8.36 & 0.1 & 3062.56 \\
\hline & Grassland & 0 & 0.57 & 869.85 & 0 & 0 & 11.6 & 0 & 882.01 \\
\hline & Wetland & 0 & 0.1 & 0 & 11.22 & 0 & 0 & 0 & 11.31 \\
\hline & Shrubland & 0 & 0.1 & 0 & 0 & 53.7 & 0.86 & 0.1 & 54.75 \\
\hline & Bare area & 0 & 0.0000063 & 0 & 0 & 0 & 233.74 & 0 & 233.74 \\
\hline & Water & 0 & 11.21 & 0.48 & 0.1 & 2.85 & 29.46 & 1681.03 & 1725.12 \\
\hline & Grand Total & 1882.26 & 3019.05 & 872.22 & 12.55 & 58.07 & 293.62 & 1681.22 & 7818.99 \\
\hline \multirow{10}{*}{ LULC 1990} & \multicolumn{9}{|c|}{ LULC 2018} \\
\hline & Classes & Cropland & Forest & Grassland & Wetland & Shrubland & Bare Area & Water & Grand Total \\
\hline & Cropland & 1645.58 & 101.43 & 0.76 & 0 & 0 & 9.6 & 0 & 1757.37 \\
\hline & Forest & 235.16 & 2869.4403 & 3.71 & 1.33 & 1.81 & 8.36 & 0.1 & 3119.9 \\
\hline & Grassland & 1.33 & 4.18 & 867 & 0 & 0 & 11.6 & 0 & 884.11 \\
\hline & Wetland & 0 & 2.85 & 0 & 11.12 & 0 & 0 & 0 & 13.97 \\
\hline & Shrubland & 0 & 4.28 & 0 & 0 & 52.08 & 0.86 & 0.19 & 57.41 \\
\hline & Bare Area & 0 & 0.0000084 & $2.70 \mathrm{E}-07$ & 0 & 0 & 217.21 & 0 & 217.21 \\
\hline & Water & 0.19 & 36.87 & 0.76 & 0.1 & 4.18 & 45.99 & 1680.93 & 1769.02 \\
\hline & Grand Total & 1882.26 & 3019.05 & 872.22 & 12.55 & 58.07 & 293.62 & 1681.22 & 7818.99 \\
\hline
\end{tabular}

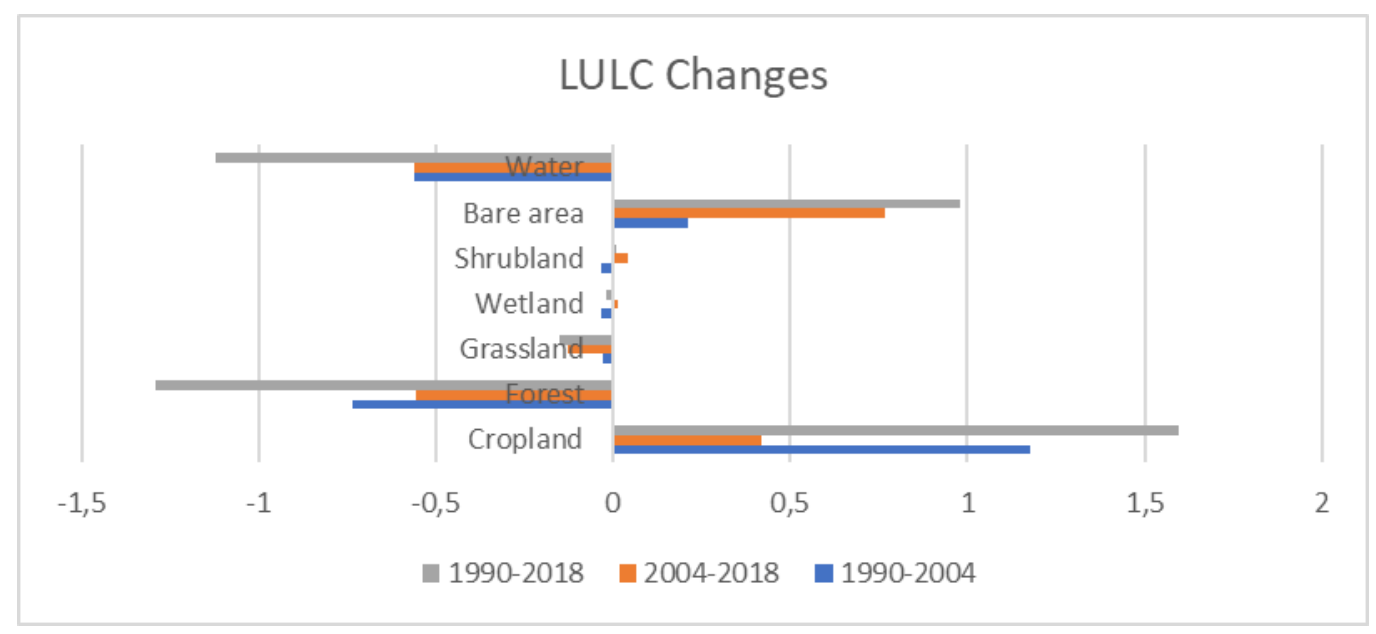

Figure 3. LULC changes of the VNP, for the periods 1990-2004, 2004-2018 and 1990-2018 in percentage 
As indicated in Figure 3, changes in LULC for the period 1990-2004 was more significant than the change for the period 2004 to 2018. Notably, changes were common across the classes in the study. The bare area increased by $0.21 \%$ from 1990 to 2004 and by $0.76 \%$ for the period 2004 to 2018 (Figure 3).

The expansion of the bare area was mainly found in the southern VNP, where more than $98 \%$ of the bare area is situated (Figure $2 A, B$ and $C$ ). It was noted that the period 1990-2004 showed significant landscape changes in all three parts of the park. This can be associated to the fact that, both the north and central parts faced civil war in DRC between 1996 and 2003 which rendered the park management inactive and contributed to illegal charcoal industry, poaching, and other deforestation activities that have increased (Crawford and Bernstein, 2008). In addition, it is also during the same period that the Soco International PLC began taking a serious interest in oil exploration around the park, especially in the central part along with subsistence agriculture, illegal logging industry and mining across the park (Schiffman, 2016; Christensen and Arsanjani, 2020).

Furthermore, during the same period (1900-2004), the Rwanda Genocide against Tutsi created almost 2 million refugees who settled in the southeast part of the park likely practicing illegal poaching, deforestation, mining, and charcoal production (Blackie et al., 2015). The impacts of this change in landscape affected the conservation in the park, for example: the dramatic drop in the elephant populations that led to dense ligneous vegetation invading the remaining savannahs (Zhang et al., 2006). The results in Figure 3 indicated that between 2004 and 2008, the bare area increased. Generally, a forest can be changed into a bare area as a result of both natural and human factors. Similarly, in the study area, the bare area is mainly situated in the southern VNP, which holds two of African's most active volcanoes (Figure 2). The period 2004 -2018 showed an increase in the bare area of $90 \%$ in the southern part of VNP (Figure 2). The bare area increase is mainly due to Nyamuragira's major eruption (2010-2011) that turned its vegetation zones into lava plains classified as bare areas (Smets et al., 2010). This eruption of Nyamuragira eruption (2010-2011) transformed $8.36 \mathrm{Km}^{2}$ of the forest, $11.6 \mathrm{Km}^{2}$ of grassland, and almost $1 \mathrm{Km}^{2}$ of shrubland into lava plains between 1990 and 2018 (Table 1).

As indicated in Table 2, the accuracy measurements were conducted to ascertain the exactness of each classified image (1990, 2004 and 2018). The image classification of the study area revealed that the overall accuracy value is $91.3 \%$, and the kappa coefficient value is 0.88 . The accuracy estimation revealed $100 \%$ producer accuracy for both water and bare areas. Further, the results in Table 2 showed that the forest and cropland have about $91.45 \%$ and $88.49 \%$ producer accuracy, respectively. In contrast, grassland, wetland, and shrubland have $81.45 \%, 36.6 \%$, and $98.65 \%$, respectively (Table 2). The estimated accuracies for the information obtained from the satellite images were judged satisfactory, and they have revealed the accuracy between a truthful standard expected and the classified image of unidentified quality.

\section{Spatio-temporal distribution of NDVI between 1990 and 2018}

The results in Figure 4 revealed a considerable decrease in the greenness within the national park since 1990.The yellow shade represented very scarce vegetation (0.16667-0.3334), and the brown spots represented non-vegetated areas. In the northern part of the study area, the vegetation started to diminish along the river in 1990 (Figure 4A). By 2004, the decline in the vegetation happened on the hill along the border of the park. The steady deterioration of the vegetation cover can be primarily attributed to increase in substance agriculture and charcoal production (Christensen and Arsanjani, 
2020). Accordingly, as shown in Figure 4C, in 2018, the entire region suffered a drastic reduction of vegetation cover. For example, in the hunting zones of Rutshuru, $90 \%$ of the total surface area was entirely degraded (Figure 4).

Table 2. LULC change confusion matrix between 1990 and 2018

\begin{tabular}{c|ccccccc|c}
\hline & Cropland & Forest & Grassland & Wetland & Shrubland & $\begin{array}{c}\text { Bare } \\
\text { area }\end{array}$ & Water & $\begin{array}{c}\text { User } \\
\text { Accuracy }\end{array}$ \\
\hline Cropland & $\mathbf{3 9 2}$ & 32 & 15 & 5 & 1 & 0 & 0 & $88.09 \%$ \\
Forest & 20 & $\mathbf{4 6 0}$ & 3 & 4 & 1 & 0 & 0 & $94.26 \%$ \\
Grassland & 21 & 9 & $\mathbf{1 0 1}$ & 4 & 0 & 0 & 0 & $74.81 \%$ \\
Wetland & 9 & 1 & 5 & $\mathbf{8}$ & 0 & 0 & 0 & $34.78 \%$ \\
Shrubland & 1 & 1 & 0 & 1 & $\mathbf{1 5 1}$ & 0 & 0 & $98.05 \%$ \\
Bare Area & 0 & 0 & 0 & 0 & 0 & $\mathbf{1 8 2}$ & 0 & $100 \%$ \\
Water & 0 & 0 & 0 & 0 & 0 & 0 & $\mathbf{1 0 2}$ & $100 \%$ \\
\hline Producer & $88.49 \%$ & $91.45 \%$ & $81.45 \%$ & $36.36 \%$ & $98.65 \%$ & $100 \%$ & $100 \%$ & \\
Accuracy & & & & & & & &
\end{tabular}

Overall accuracy: $91.3 \%$, Kappa statistics: 0.88

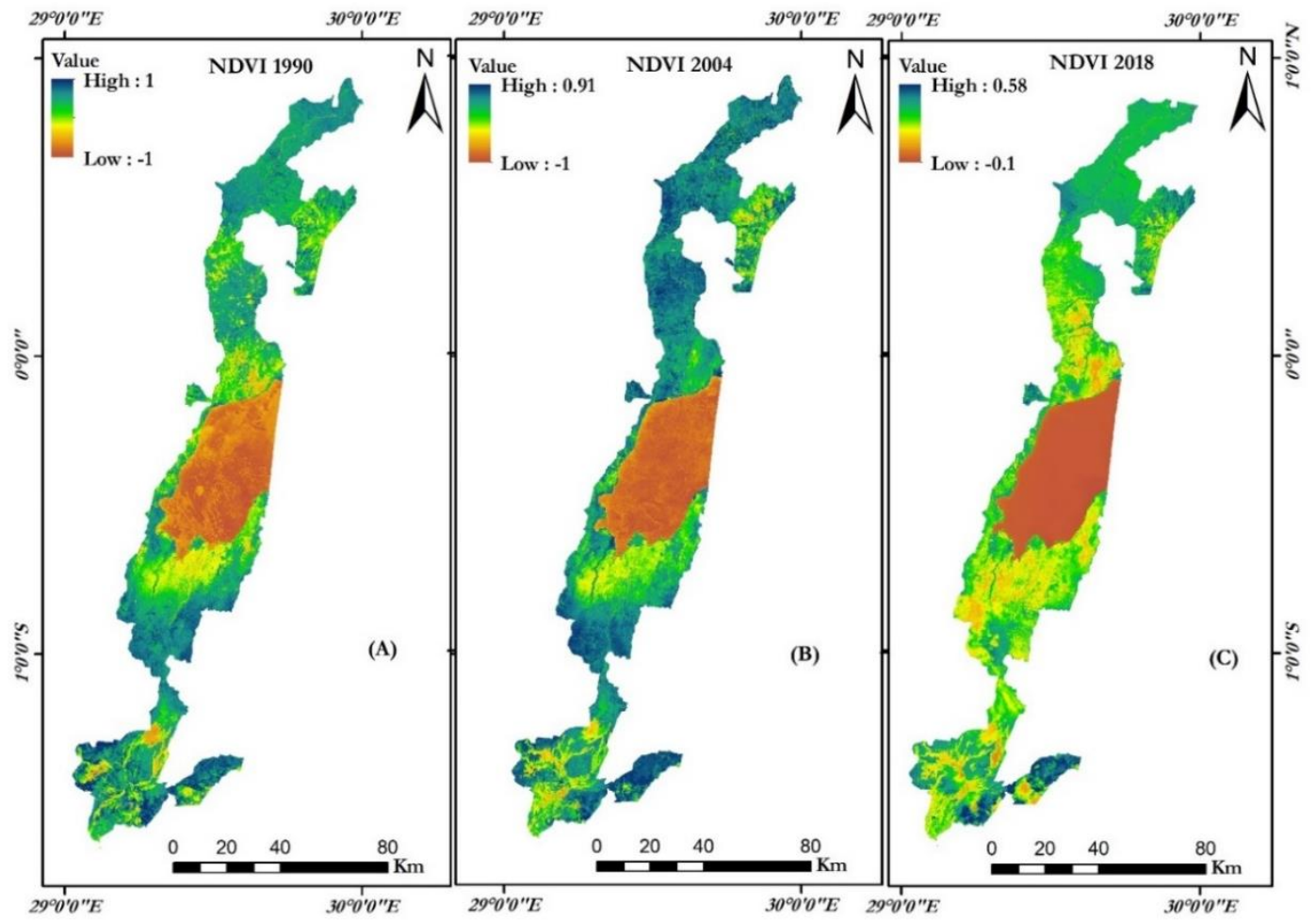

Figure 4. Spatial and temporal NDVI distribution at Virunga National Park in (A) 1990, (B) 2004 and $(C) 2018$

As shown in Figure 4, NDVI values within VNP dropped from 0.967742 to -0.123094 . Such a drop suggests that the slightly forested areas probably became grasslands or shrubland. The densely vegetated areas observed to the western park are absent in 2018. Similarly, Jones (2019) observes that there are more mildly forested areas and less 
vegetation in the same region. Moreover, the results in Figure $4 C$ revealed a significant loss of highly dense forests in the southern part of the study area. The volcanoes located to the east of the national park showed that highest vegetation decline between 1990 and 2018. It can be noted that the vegetation decline, southern part (Figure $4 C$ ) is mainly due to the volcanic activity that takes place almost every year (Smets et al., 2010) and have severely affected the dense forest where the heads of trees were partly burned by acid rainfalls and volcanic plume (Vaselli et al., 2010). The coral trails seen near the volcanoes are recently dried lava flows (Figure 4C). A perturbation event was observed from 1990 to 2018 over a vast region of the southern part of the study area, with a North East -South West spatial distribution (Figure $4 B$ and $C$ ).

The spatial distribution estimate ranged between (-0.123094 to 0.583163$)$ across Virunga National Park (Figure 4C). Lava flow, gas emission, and volcanic plume contribute to the intensity of the NDVI perturbation pattern, as argued by other previous studies (Grainger et al., 2013). The spatial distribution of the perturbation promoted by a volcanic eruption (Lava flow and Volcanic plume deposit) from Nyiragongo and Nyamuragira activities during the period 1990-2018 were noted by observing sudden changes in NDVI temporal dynamics (Table 3). The NDVI perturbation pattern was observed in a North-East (NE) and South-West (SW) part of the park (Figure 4C). This likely agrees with Cuoco et al. (2013) that the Southwest of Mount Nyamuragira records the highest intensity of volcanic plume dispersion. Equally, Wauthier et al. (2009) pointed the same location as the direction of lava flow originating from the Nyiragongo volcano in January 2002. The NE spatial distribution also coincide with the direction of Nyamuragira lava flows for the 2001 and 2002 eruptions as mapped by Smets (2010) and Li et al. (2018).

Table 3. The LULC classes and their corresponding ranges of NDVI values

\begin{tabular}{c|c|c|c}
\hline LULC classes & NDVI range 1990 & NDVI range 2004 & NDVI range 2018 \\
\hline Cropland & $0.3-0.6$ & $0.2-0.7$ & $0.15-0.45$ \\
Forest & $0.4-0.96$ & $0.3-0.92$ & $0.4-0.56$ \\
Grassland & $0.1-0.61$ & $0.2-0.55$ & $0.08-0.38$ \\
Wetland & $0.06-0.5$ & $0.0-0.4$ & $0.05-0.4$ \\
Shrubland & $0.2-0.4$ & $0.18-0.55$ & $0.1-0.4$ \\
Bare area & $\mathbf{0 . 0}-0.3$ & $0.01-0.36$ & $0-0.22$ \\
Water & $-0.2-0.10$ & $-0.5--0.02$ & $-0.1-0.19$ \\
\hline
\end{tabular}

In addition, the results in Figure 4 showed that the southeast part of the park for the period 1990-2004, NDVI perturbation was previously associated at a large extent. This again, can be associated to the reason that the Rwanda Genocide against Tutsi created more than 1 million refugees. The displacement Rwandan refugees to build settlements within the park contributed to illegal poaching, mining and deforestation (Kingston, 2017). Thereafter, the authors performed the NDVI Change detection as illustrated in Figure 5. It was noticed that the annual change of the trend in NDVI showed that the maximum vegetation cover for each year was 0.440708 , while the minimum was -0.296286 . The detection of changes was obtained by using the annual trends in NDVI multiplied by the significance value (p-value). The calculation in Figure 5 showed that $2.7 \%$ significantly improved, $4.7 \%$ slightly improved, while $42 \%$ of the study area showed stable or no change areas. Also, Figure 5 showed that $35.7 \%$ was slightly degraded, and $14.8 \%$ was significantly degraded. Significant degradation was mainly 
observed in the central parts of the park where the population of the fourteen fishing villages increased between 1990 and 2018. The southwest part of the park was also significantly degraded due to volcanic eruptions. Nyamuragira's lava plain is a significant contributor to the degradation apart from the direction of Nyamuragira and Nyiragongo plume, ash, and gases.

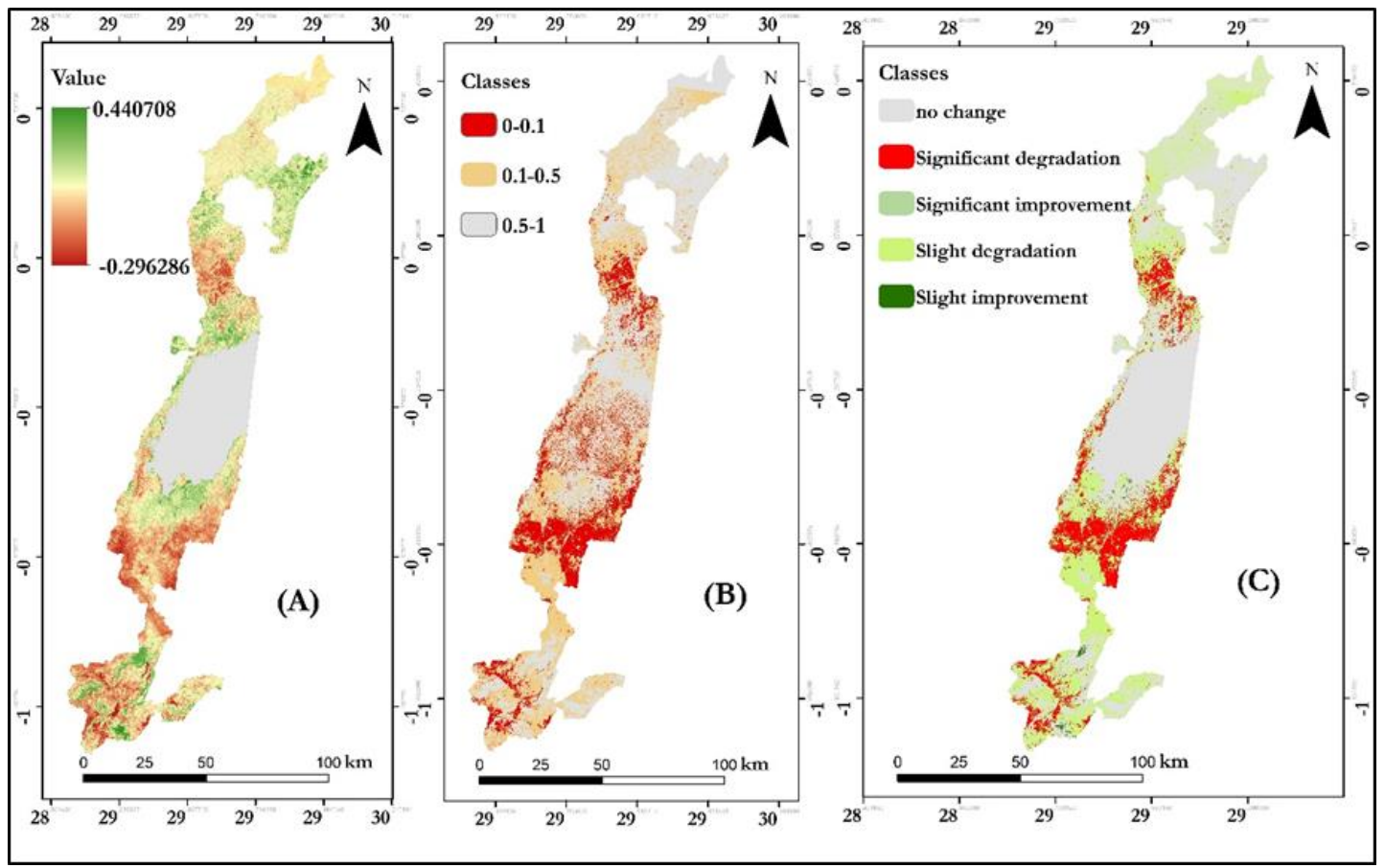

Figure 5. a) Annual change trends in NDVI, b) Significance ( $P$-Value) of the change trends in $N D V I, c)$ The overall trends classified in into five types: significant improvement, slight improvement, stable or no vegetated, slight degradation and significant degradation

\section{NDVI - precipitation and temperature relationship}

In order to isolate the effects of volcanic eruption in correlation with other environmental aspects that might disturb the state of the NDVI, it is required to find out the contribution of climate variables on the landscape (Ford et al., 2013). For this study, NDVI, precipitation and temperature relationships enabled the authors to isolate the impact of volcanic eruption on the national park's landscape, mainly in one component.

The results in Figure $6 \mathrm{~A}$ indicate that the NDVI-precipitation correlation was positive in the north zone of the VNP, which suggests that the increase of rainfall was proportionally increasing with the NDVI. However, for the southern part, the correlation was negative, which reveals that the rise in precipitation does not correlate with the increase in NDVI. The main direction of volcanic plume represents the negative correlation. Notably, lower NDVI is detected for a pixel compared to the expected value for the same type of vegetation at the same elevation after experiencing rainfall (Balagizi et al., 2018).

Regarding the correlation between temperature and NDVI, the results in Figure $6 B$ exhibited a positive correlation between temperature and NDVI. The increase of temperature affected the NDVI positively in the northern, central, and southern parts of the study area. The results implied that the temperature did not affect the vegetation 
greenness for the period between 1990 and 2018. Therefore, the decline of NDVI in the south of the park was likely attributed to two reasons including: (i) the lava flow that changed the forest zones into lava plains (Figure 2) and (ii) volcanic plume deposits and volcanic gases emission that diminished the vegetation greenness. The volcanic plume and gases are previously reported, are mainly oriented to the West and South-West from the location of Nyamuragira and Nyiragongo volcanoes in the southern part of our study area due to the dominant regional winds (Vaselli et al., 2010; Balagizi et al., 2018). The NDVI-Precipitation and temperature relationship results isolated the effects of volcanic eruption on the landscape fragmentation from the impact of climatic variables effects.

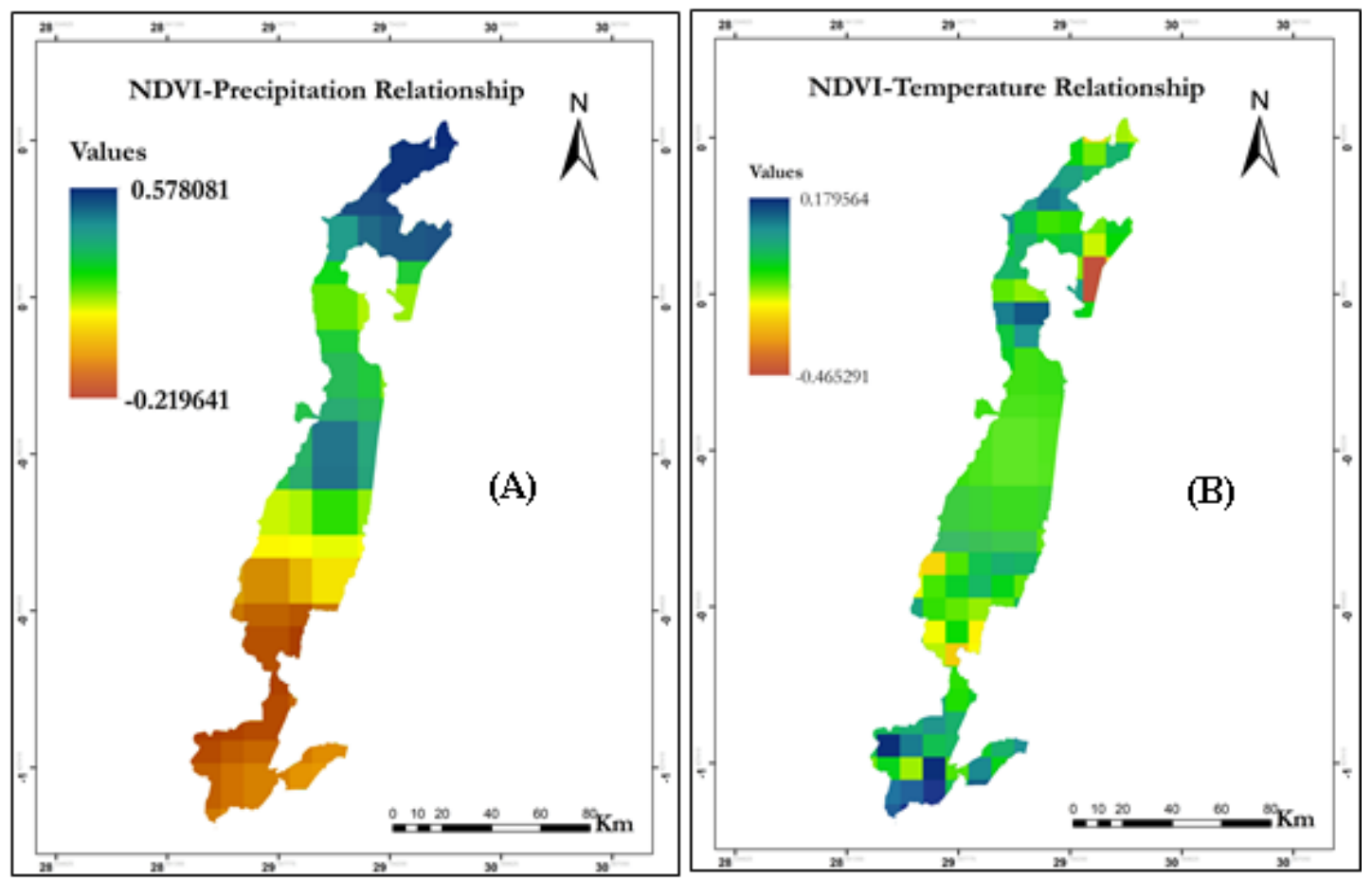

Figure 6. NDVI-precipitation (A) and NDVI temperature Correlation (B)

\section{Landscape change and Chimpanzee's habitats fragmentation}

Chimpanzees occupy the Tongo forest $\left(10 \mathrm{Km}^{2}\right)$ located to the north of the Nyamuragira's lava flow south of the VNP. Since the 1938-40 eruption, flank eruptions have dominated the Nyamuragira activity (Mukendi et al., 2013). Lava flows from these eruptions have gradually reduced the densely forested area. When Nyamuragira erupted, new volcanic surfaces were created by lava and replaced the habitats of chimpanzees in the Tongo forest and other prevailing wildlife along the volcano's lower slopes (Figure 2C). As such, the population of Chimpanzees in the Tongo forest became vulnerable to the Nyamuragira eruption events. In 1990, the number of chimpanzees in the Tongo was approximate 50, but as a consequence of habitat loss, the number had declined to 32 in 2005 (van Leeuwen et al., 2020). Based on the results of this this study (Figure 2C), it can be noted that the dense forest, which is habitat to chimpanzees, was destroyed by Nyamuragira eruptions.

In addition, it is reported that the lava flows built a new landform (lava plains) at the same time destroying the chimpanzee's habitats zones. The volcanic plume deposit and 
gas emissions affected the chimpanzee's food, as argued by Balagizi et al. (2018). During the 2010-2011 events, almost 40 chimpanzees were surrounded by lava, and the plants that they consume became coated with abrasive volcanic ash. Emissions of lava flows, toxic gases, and forest fires, resulting from volcanic eruption severely affected VNP's Chimpanzees population that had already been isolated by habitat destruction. During the period of this study, it was noticed that the chimpanzees residing along the slopes of Nyamuragira were threatened by the eruptions, especially the January 2010 eruption (Cuoco et al., 2013). In addition to the direct impact on mortality, further loss of habitat due to these eruptions reduces the chimpanzee population.

\section{Comparison between anthropogenic activities and volcanic eruption disaster in the park}

The results in Figure 2 and Table 1 showed that anthropogenic activities were the main challenge faced by VNP during the study's period. There was a significant change in the landscape for the northern and central parts of the park that are not affected by the volcanic eruption. For the study's period (1990-2018), the national park lost $235.16 \mathrm{~km}^{2}$ of forest and $1.33 \mathrm{Km}^{2}$ of grassland that changed into cropland (Table 1). Also, $60 \%$ of the forest loss that changed into agriculture is located in the North and central VNP while $40 \%$ forest loss was shown in the south. The forest portion that turned into the bare area in the south was estimated at $8.36 \mathrm{Km}^{2}$ (Table 1). Only $0.05 \%$ of the forest portion changed into a bare area in the north and central part while $99.5 \%$ of forest turned into bare area in the south. During the same period, the grassland portion that the national park lost due to the volcanic eruption was $11.6 \mathrm{Km}^{2}$ (Table 1). This showed that anthropogenic activities affected the national park more than ten times than volcanic eruptions did. However, the difference is that for the southern part where the forest is destroyed by lava, it will take much time for the vegetation cover to colonize, as discussed by Liao et al. (2018). The NDVI perturbation also is permanent in the southwest because of the persistent gas emission from the volcanoes (Vaselli et al., 2010). Thus, the volcanic eruption had a significant contribution to the VNP landscape change, but it is not the main challenge facing by the park.

\section{Conclusion}

This study aimed to compare the factors conditioning the landscape change during volcanic eruption at Virunga National Park located in the East Africa. Remote Sensing and GIS were the main tools used to collect and analyze relevant data (Landsat images) and climate factors (rainfall and temperature) ranging from1990 to 2018. The results revealed that the north and central parts changed in response to human activities. The civil wars in the DRC, illegal charcoal production, expansion of cropland within the park were the key drivers. Nyiragongo and Nyamuragira's lava flows changed vegetation zones into lava plains which led to land cover forest $\left(8 \mathrm{Km}^{2}\right)$, grassland $\left(11 \mathrm{Km}^{2}\right)$, and shrubland $\left(1 \mathrm{Km}^{2}\right)$. This then, formed a new land (lava plains), then the habitat of chimpanzees was lost, and their volcanic plume and permanent gas emission were the leading causes to NDVI perturbation in the southwest region of VNP. However, precipitation and temperature did not contribute to NDVI perturbation in the southern VNP. Although volcanic eruption changed the landscape in the south, the largest part of land loss resulted from anthropogenic activities, especially in the north, central and southeast VNP. The developments were consistent with the fact that VNP lost $235.16 \mathrm{Km}^{2}$ of forest and 
$1.33 \mathrm{Km}^{2}$ of grassland that changed into cropland during the period under investigation. While during the same period the land cover loss due to volcanic eruption was only $8 \mathrm{Km}^{2}$ of forest and $11.6 \mathrm{Km}^{2}$ of grassland; Therefore, it good to sustain the conservation, improvement, and rehabilitation of the VNP. Incessant observation of land changes in the VNP is also necessary to keep updating management planning. Future research and remote-sensing based activities can utilize this study as a reference considering that it is new for the VNP. Furthermore, year by year LULUC change detection at the study area is suggested to see if human activities do not influence change on volcanic park landscape compared to natural factors.

Funding. This study was supported by the Second Tibetan Plateau Scientific Expedition and Research program (No.2019QZKK0401) and the National Key Research and Development Program of China (No.2016FYC0503306).

Data Availability Statement. The source of all the data used in this study is provided in the manuscript.

Acknowledgements. The authors express their gratitude to the United State Geological Survey (USGS) for making available satellites imageries, the University of Chinese Academy of Sciences scholarship. The authors are grateful to Xinjiang Institute of Ecology and Geography for enabling environment for research and professor Yang Zhaoping for the supervision of this work.

Competing interests. The authors declare no conflict of interests.

\section{REFERENCES}

[1] Allard, P., Baxter, P., Halbwachs, M., Komorowski, J.-C. (2002): The January 2002 eruption of Nyiragongo volcano (Dem. Repub. Congo) and related hazards: observations and recommendations. - Final Report of the French-British Team, Paris, 2002.

[2] Andren, H. (1994): Effects of habitat fragmentation on birds and mammals in landscapes with different proportions of suitable habitat: a review. - Oikos 71: 355-366.

[3] Balagizi, C. M., Kasereka, M. M., Cuoco, E., Liotta, M. (2018): Influence of moisture source dynamics and weather patterns on stable isotopes ratios of precipitation in CentralEastern Africa. - Science of the Total Environment 628-629: 1058-1078.

[4] Baxter, P. J., Ancia, A. (2002): Human health and vulnerability in the Nyiragongo volcano crisis, Democratic Republic of Congo 2002. - Final report to the World Health Organisation.

[5] Binsangou, S., Suspense, I. A., Ibocko, L., Louvouandou, L., Tchindjang, M., Koubouana, F. (2018): Urban Growth and Deforestation by Remote Sensing in the Humid Tropical Forest of Congo Bassin: Case of Impfondo in Republic of Congo. - American Journal of Environment and Sustainable Development 3(3): 46-54.

[6] Blackie, L. E. R., Jayawickreme, E., Forgeard, M. J. C., Jayawickreme, N. (2015): The protective function of personal growth initiative among a genocide-affected population in Rwanda. - Psychological Trauma: Theory, Research, Practice, and Policy 7(4): 333.

[7] Christensen, M., Arsanjani, J. J. (2020): Stimulating implementation of sustainable development goals and conservation action: predicting future land use/cover change in Virunga National Park, Congo. - Sustainability 12(4): 1570.

[8] Crawford, A., Bernstein, J. (2008): MEAs, conservation and conflict: A case study of Virunga National Park, DRC. - International Institute for Sustainable Development (IISD).

[9] Cuoco, E., Tedesco, D., Poreda, R. J., Williams, J. C., De Francesco, S., Balagizi, C., Darrah, T. H. (2013): Impact of volcanic plume emissions on rain water chemistry during 
the January 2010 Nyamuragira eruptive event: implications for essential potable water resources. - Journal of hazardous materials 244: 570-581.

[10] DeRose, R. J., Long, J. N., Ramsey, R. D. (2011): Combining dendrochronological data and the disturbance index to assess Engelmann spruce mortality caused by a spruce beetle outbreak in southern Utah, USA. - Remote sensing of environment 115(9): 2342-2349.

[11] Desclee, B., Simonetti, D., Mayaux, P., Achard, F. (2013): Multi-sensor monitoring system for forest cover change assessment in Central Africa. - IEEE Journal of Selected Topics in Applied Earth Observations and Remote Sensing 6(1): 110-120.

[12] Edwards Jr, D. B., Okitsu, T., da Costa, R., Kitamura, Y. (2018): Organizational legitimacy in the global education policy field: Learning from UNESCO and the Global Monitoring Report. - Comparative Education Review 62(1): 31-63.

[13] Estoque, R. C., Murayama, Y., Lasco, R. D., Myint, S. W., Pulhin, F. B., Wang, C., Ooba, M., Hijioka, Y. (2018): Changes in the landscape pattern of the La Mesa Watershed-The last ecological frontier of Metro Manila, Philippines. - Forest Ecology and Management 430: 280-290.

[14] Ford, K. R., Ettinger, A. K., Lundquist, J. D., Raleigh, M. S., Lambers, J. H. R. (2013): Spatial heterogeneity in ecologically important climate variables at coarse and fine scales in a high-snow mountain landscape. - PLoS ONE 8(6): e65008.

[15] Grainger, R. G., Peters, D. M., Thomas, G. E., Smith, A. J. A., Siddans, R., Carboni, E., Dudhia, A. (2013): Measuring volcanic plume and ash properties from space. - Geological Society, London, Special Publications 380(1): 293-320.

[16] Ibáñez, I., Katz, D. S. W., Peltier, D., Wolf, S. M., Barrie, B. T. C. (2014): Assessing the integrated effects of landscape fragmentation on plants and plant communities: the challenge of multiprocess-multiresponse dynamics. - Journal of Ecology 102(4): 882-895.

[17] Kingston, L. N. (2017): Bringing Rwandan refugees 'home': The cessation clause, statelessness, and forced repatriation. - International Journal of Refugee Law 29(3): 417437.

[18] Li, L., Bakelants, L., Solana, C., Canters, F., Kervyn, M. (2018): Dating lava flows of tropical volcanoes by means of spatial modeling of vegetation recovery. - Earth Surface Processes and Landforms 43(4): 840-856.

[19] Liao, J., Jia, Y., Tang, L., Huang, Q., Wang, Y., Huang, N., Hua, L. (2018): Assessment of urbanization-induced ecological risks in an area with significant ecosystem services based on land use/cover change scenarios. - International Journal of Sustainable Development \& World Ecology 25(5): 448-457

[20] Lin, Y.-X., Chen, M.-H., Lin, B.-S., Su, C.-H. (2020): Asymmetric effects of cultural and natural World Heritage Sites on tourism receipts. - Current Issues in Tourism 23(24): 31343147.

[21] MacLean, M. G., Congalton, R. G. (2012): Map accuracy assessment issues when using an object-oriented approach. - Proceedings of the American Society for Photogrammetry and Remote Sensing Annual Conference 2012, Sacramento, CA, USA.

[22] Marijnen, E. (2018): Public authority and conservation in areas of armed conflict: Virunga National Park as a 'state within a state'in eastern Congo. - Development and Change 49(3): 790-814.

[23] Meskell, L. (2013): UNESCO's World Heritage Convention at 40: Challenging the economic and political order of international heritage conservation. - Current anthropology 54(4): 483-494.

[24] Michellier, C., Kervyn, M., Barette, F., Syavulisembo, A. M., Kimanuka, C., Mataboro, S. K., Hage, F., Wolff, E., Kervyn, F. (2020): Evaluating population vulnerability to volcanic risk in a data scarcity context: The case of Goma city, Virunga volcanic province (DRCongo). - International journal of disaster risk reduction 45: 101460.

[25] Mind'je, R., Li, L., Amanambu, A. C., Nahayo, L., Nsengiyumva, J. B., Gasirabo, A., Mindje, M. (2019): Flood susceptibility modeling and hazard perception in Rwanda. International journal of disaster risk reduction 38: 101211. 
[26] Mitchell, M. G. E., Suarez-Castro, A. F., Martinez-Harms, M., Maron, M., McAlpine, C., Gaston, K. J., Johansen, K., Rhodes, J. R. (2015): Reframing landscape fragmentation's effects on ecosystem services. - Trends Ecol Evol. 30(4): 190-198.

[27] Mukendi, E. M., Bwira, K. S., Mutoba, B. M., Tunda, F. M. (2013): On an XML and OWL Computer Ontology for the Representation if Mammals in DRC. - International Journal of Computer Science Issues (IJCSI) 10(3): 330.

[28] Mutaqin, B. W., Lavigne, F., Hadmoko, D. S., Malawani, M. N. (2019): Volcanic eruptioninduced tsunami in Indonesia: A review. - IOP Conference Series: Earth and Environmental Science 256: 012023.

[29] Ndayisaba, F., Guo, H., Isabwe, A., Bao, A., Nahayo, L., Khan, G., Kayiranga, A., Karamage, F., Muhire, E. N. (2017): Inter-Annual Vegetation Changes in Response to Climate Variability in Rwanda. - Journal of Environmental Protection 8(04): 464.

[30] Orimoloye, I. R., Mazinyo, S. P., Kalumba, A. M., Nel, W., Adigun, A. I., Ololade, O. O. (2019): Wetland shift monitoring using remote sensing and GIS techniques: landscape dynamics and its implications on Isimangaliso Wetland Park, South Africa. - Earth Science Informatics 12(4): 553-563.

[31] Osipova, E., Wilson, L., Blaney, R., Shi, Y., Fancourt, M., Strubel, M., Salvaterra, T., Brown, C., Verschuuren, B. (2014): The benefits of natural World Heritage: Identifying and assessing ecosystem services and benefits provided by the world's most iconic natural places. - IUCN.

[32] Pareta, K., Pareta, U. (2019): Identification of Vulnerable Areas to Natural Hazards Along Rapti River System in UP (India) Using Satellite Remote Sensing Data and GIS. American Journal of Geophysics, Geochemistry and Geosystems 5(3): 91-103.

[33] Rolo, V., Olivier, P. I., Pfeifer, M., van Aarde, R. J. (2018): Functional diversity mediates contrasting direct and indirect effects of fragmentation on below-and above-ground carbon stocks of coastal dune forests. - Forest Ecology and Management 407: 174-183.

[34] Rwanga, S. S., Ndambuki, J. M. (2017): Accuracy assessment of land use/land cover classification using remote sensing and GIS. - International Journal of Geosciences 8(04): 611.

[35] Schiffman, R. (2016): We risk our lives daily for Virunga National Park. - New Scientist 231(3086): 38-39.

[36] Smets, B., Wauthier, C., d'Oreye, N. (2010): A new map of the lava flow field of Nyamulagira (DR Congo) from satellite imagery. - Journal of African Earth Sciences 58(5): 778-786.

[37] Song, C., Woodcock, C. E., Seto, K. C., Lenney, M. P., Macomber, S. A. (2001): Classification and Change Detection Using Landsat TM Data: When and How to Correct Atmospheric Effects? - Remote Sensing of Environment 75(2): 230-244.

[38] Tazieff, H. (1977): An exceptional eruption: Mt. Niragongo, Jan. 10 th, 1977. - Bulletin of Volcanology 40(3): 189-200.

[39] Tedesco, E. F., Noah, P. V., Noah, M., Price, S. D. (2002): The supplemental IRAS minor planet survey. - The Astronomical Journal 123(2): 1056.

[40] van Leeuwen, K. L., Hill, R. A., Korstjens, A. H. (2020): Classifying chimpanzee (Pan troglodytes) landscapes across large-scale environmental gradients in Africa. International Journal of Primatology 41(6): 800-821.

[41] Vaselli, O., Tassi, F., Tedesco, D., Cuoco, E., Nisi, B., Mapedano, M. Y. (2010): Environmental impact of the Nyiragongo volcanic plume after the January 2002 eruption. Active volcanism and continental rifting (AVCoR-2007). - Luxembourg: Cahiers du Centre Européen de Géodynamique et de Séismologie.

[42] Wauthier, C., Cayol, W., Kervyn, F., d'Oreye, N. (2009): The January 2002 eruption of Nyiragongo volcano (DRC) captured by InSAR. - 2009 IEEE International Geoscience and Remote Sensing Symposium.

[43] Zhang, Q., Justice, C. O., Jiang, M., Brunner, J., Wilkie, D. S. (2006): A GIS-based assessment on the vulnerability and future extent of the tropical forests of the Congo Basin. - Environmental monitoring and assessment 114(1-3): 107-121. 